\title{
Evaluation of reference genes for reverse transcription quantitative PCR analyses of fish-pathogenic Francisella strains exposed to different growth conditions
}

Espen Brudal ${ }^{1,2}$, Hanne Cecilie Winther-Larsen ${ }^{2,3}$, Duncan John Colquhoun ${ }^{4}$ and Samuel Duodu ${ }^{4^{*}}$

\begin{abstract}
Background: Reverse transcription quantitative PCR has become a powerful technique to monitor mRNA transcription in response to different environmental conditions in many bacterial species. However, correct evaluation of data requires accurate and reliable use of reference genes whose transcription does not change during the course of the experiment. In the present study exposure to different growth conditions was used to validate the transcription stability of eight reference gene candidates in three strains from two subspecies of Francisella noatunensis, a pathogen causing disease in both warm and cold water fish species.
\end{abstract}

Results: Relative transcription levels for genes encoding DNA gyrase (gyrA), RNA polymerase beta subunit (rpoB), DNA polymerase I (po/A), cell division protein (ftsZ), outer membrane protein (fopA), riboflavin biosynthesis protein (ribC), 165 ribosomal RNA (16S rRNA) and DNA helicases (uvrD) were quantified under exponential, stationary and iron-restricted growth conditions. The suitability of selected reference genes for reliable interpretation of gene expression data was tested using the virulence-associated intracellular growth locus subunit C (ig/C) gene.

Conclusion: Although the transcription stability of the reference genes was slightly different in the three strains studied, fopA, ftsZ and polA proved to be the most stable and suitable for normalization of gene transcription in Francisella noatunensis ssp.

Keywords: Gene expression, RT-qPCR, Francisella noatunensis, Fish, Francisellosis

\section{Background}

Systemic infection caused by the Gram-negative bacterium Francisella noatunensis remains a serious threat to Atlantic cod Gadhus morhua L. farming in Norway. Similar diseases associated with different strains of $F$. noatunensis have been reported in both fresh- and seawater farmed fish in Taiwan and Japan [1] Chile [2], America [3], and Great Britain [4]. Large knowledge gaps exist, however, in relation to pathogenesis and mechanisms of disease development. Recent genome analysis has revealed the presence of several virulence determinant loci in fish pathogenic Francisella spp., which share a high degree of sequence identity with the

\footnotetext{
* Correspondence: samuel.duodu@vetinst.no

${ }^{4}$ Section for Bacteriology, Norwegian Veterinary Institute, PO Box 750, Sentrum 0106, Oslo, Norway

Full list of author information is available at the end of the article
}

human pathogen F. tularensis [5]. Some of the most interesting genes are localized on the 33-kb Francisella Pathogenicity Island (FPI) [6,7], including genes of the intracellular growth locus operon iglABCD. The $i g l C$ gene has also been shown to be important for virulence in F. noatunensis ssp. orientalis $[8,9]$.

One way of investigating disease pathogenesis at the molecular level is by reverse transcription quantitative PCR (RT-qPCR) analysis of gene transcription at different stages of disease development. However, use of RT-qPCR for gene transcription studies has its pitfalls. The method has an intrinsic requirement for normalization of target gene transcription levels against that of reference genes to ensure reliable data interpretation, as exemplified by Dedha et al. [10], and Guitierrez et al. [11]. The use of a minimum of three validated reference genes has 
been suggested [12]. Similarly, the importance of standardization of RNA extraction techniques, evaluation of RNA quality and the use of reference genes has been emphasized in several publications [13-15].

In this study, the transcriptional stability of eight reference genes in Francisella noatunensis ssp. was investigated under three different environmental conditions using the excel-based software geNorm [12]. To accurately quantify changes in transcription levels of specific mRNA targets, the $i g l C$ gene was chosen and normalized against the selected reference genes subjected to the same growth conditions using the established protocol.

\section{Methods}

\section{Bacterial strains and growth conditions}

The three isolates used in this study represent different fish pathogenic $F$. noatunensis strains. $F$. noatunensis spp. noatunensis $\left(\mathrm{NCIMB} 14265^{\mathrm{T}}\right.$ ) was isolated from diseased Atlantic cod Gadus morhua L. in Norway [16]. F. noatunensis ssp. noatunensis PQ 1106 was isolated from diseased Atlantic salmon Salmo salar L. in Chile [2]. F. noatunensis ssp. orientalis DSM21254 ${ }^{\mathrm{T}}$ was isolated from three-line grunt, Parapristipoma trilinineatum L. in Japan [1].

The strains were stored at $-80^{\circ} \mathrm{C}$ in growth medium containing 20\% glycerol. Prior to experimentation cultures were maintained on Eugon Chocolate Ferric Agar (ECFA) plates and incubated at $20-22^{\circ} \mathrm{C}$. ECFA consists of 30.4 g/l BD Bacto ${ }^{\text {TM }}$ Eugon Broth (Difco Laboratories) $15 \mathrm{~g} / \mathrm{l}$ Microbiology Agar (Merck), 5\% bovine blood (Håtunlab $\mathrm{AB}$ ) and $2 \mathrm{mM} \mathrm{FeCl}_{3}$ (Sigma-Aldrich). BD Bacto ${ }^{\mathrm{TM}}$ Eugon Broth supplemented with $2 \mathrm{mM}$ $\mathrm{FeCl}_{3}$ (EBF) was used for liquid cultures.

The experimental conditions tested included early exponential growth phase, stationary growth phase and an iron-depleted environment. For the growth phase studies, $10 \mathrm{ml}$ EBF was inoculated with colony material from ECFA plates and incubated at $20-22^{\circ} \mathrm{C}$ with gentle shaking $(150 \mathrm{rpm})$. Two parallel cultures were made for each strain on subsequent days. Optical density (OD) at $600 \mathrm{~nm}$ was measured with a Genesys 20 spectrophotometer (Thermo Scientific). For the iron depletion studies, the strains were inoculated into $10 \mathrm{ml} E B F$ and incubated for 3 days at $22^{\circ} \mathrm{C}$ with shaking. The bacteria were subsequently pelleted by centrifugation (4000 g, $5 \mathrm{~min}$ ), resuspended in fresh Eugon Broth without supplemented $\mathrm{FeCl}_{3}$ (EB) and grown for $24 \mathrm{hrs}$. Thereafter, the cultures were washed twice with PBS and once with EB supplemented with 2, 2'-dipyridyl (DP; SigmaAldrich) at a final concentration of $100 \mu \mathrm{M}$ (EB/DP), to ensure removal of iron carried over from the previous medium. Washed bacteria were then used to inoculate cultures of EBF or EB/DP. The cultures were grown with shaking at $22^{\circ} \mathrm{C}$ for $24 \mathrm{~h}$, after which the cells were immediately stabilized by adding 2 volumes of RNAProtect Bacteria reagent (QIAGEN).

\section{Primer design, PCR efficiency}

Potential reference genes were chosen based on a literature review of reference genes used in RT-qPCR for Francisella spp. (see Additional file 1), in addition to other commonly used bacterial reference genes. Primers were designed to target eight potential reference genes and the putative virulence gene $\mathrm{iglC}$ (see Table 1). The examined reference genes were $u v r D$ (helicase, separates two annealed nucleic acid strands during DNA replication, transcription, translation, recombination, DNA repair and ribosome biogenesis) rров ( $\beta$ subunit of RNA polymerase), gyrA (DNA topoisomerase II), polA (DNA polymerase I), fopA (Francisella outer membrane protein A), fts $Z$ (encoding a prokaryotic cytoskeletal protein important for cell division), ribC (riboflavin synthetase) and $16 S$ rRNA (small ribosomal RNA subunit). Primer efficiencies were determined using 10-fold dilution series of cDNA and genomic DNA as template for $\mathrm{qPCR}$ reactions.

\section{RNA isolation and reverse transcription}

Bacterial cells were stabilized with RNAProtect Bacteria Reagent (QIAGEN) and total RNA extracted from $500 \mu \mathrm{l}$ early exponential growth phase cultures and $250 \mu \mathrm{l}$ stationary growth phase cultures using RNeasy Mini Kit (QIAGEN) according to the manufacturer's instructions. A 15 minute on-column DNase digestion with RNase-Free DNase (QIAGEN) was performed to ensure removal of contaminating genomic DNA, as suggested by the manufacturer. For each strain, three RNA extractions were performed from exponential and stationary growth phases, while two extractions were performed for the iron-depletion experiment. RNA concentration and purity, determined by $260 / 280$ and 260 / 230 ratios, were measured with a Nanodrop ND-1000 spectrophotometer (Nanodrop Technologies Inc.). RNA integrity was assessed by gel electrophoresis as described by BioRad Technical Note 5396 [18] using $500 \mathrm{ng}$ of the extracted RNA and evaluation of the ratio between the bands corresponding to $16 \mathrm{~S}$ and $23 \mathrm{~S}$ ribosomal RNA. Reverse transcription of $1 \mu \mathrm{g}$ extracted RNA in $20 \mu \mathrm{l}$ reactions was performed with QuantiTect Reverse Transcription kit (QIAGEN) using random primers according to the manufacturer's instructions. A control with omitted reverse transcriptase was performed for each extraction to check for the presence of contaminating genomic DNA. After reverse transcription, the samples were diluted 1:10 in DEPC treated $\mathrm{H}_{2} \mathrm{O}$ and used as templates for qPCR. 
Table 1 Primers used for RT-qPCR in the present study

\begin{tabular}{|c|c|c|c|c|c|c|c|}
\hline & & & & $\begin{array}{l}\text { Primer } \\
\text { efficiency }\end{array}$ & & & \\
\hline $\begin{array}{l}\text { Target } \\
\text { gene }\end{array}$ & Forward primer $\left(5^{\prime}-3^{\prime}\right)$ & Reverse primer $\left(5^{\prime}-3^{\prime}\right)$ & $\begin{array}{l}\text { Amplicon } \\
\text { size }\end{array}$ & $\begin{array}{c}\text { Fn. ssp. } \\
\text { noatunensis }\end{array}$ & $\begin{array}{l}\text { Fn. ssp. } \\
\text { orientalis }\end{array}$ & Gene ID & Position \\
\hline uvrD & ACTATTTGTCGCGGGTCCTT & TCAAAGAAACGAAAACCTCCA & $82 \mathrm{bp}$ & 2.050 & 1.959 & 12951493 & $\begin{array}{l}596634- \\
596715\end{array}$ \\
\hline$r p o B$ & GTGGTAAAGCGCAATTTGGT & CAGCACCATATGCTTGTAACG & $72 \mathrm{bp}$ & 1.986 & 1.988 & 12951517 & $\begin{array}{l}620011- \\
620082\end{array}$ \\
\hline gyrA & CGAGCTITACGAGCTGCTTC & TCTITTAGAGAACCCTAAAGAGGCT & $87 \mathrm{bp}$ & 1.982 & 2.000 & 12952071 & $\begin{array}{l}1187616- \\
1187702\end{array}$ \\
\hline polA & AGCTGGAACTGGTCGTAATCA & ATCAGCATCTTCAGCAGCATA & $82 \mathrm{bp}$ & 1.959 & 1.950 & 12951484 & $\begin{array}{l}584274- \\
584355\end{array}$ \\
\hline fopA & TACTGGTGCATGGGATGTTG & TCTTGGAGCCATTGTCTGAA & $100 \mathrm{bp}$ & 1.902 & 1.938 & 12952182 & $\begin{array}{l}1297252- \\
1297351\end{array}$ \\
\hline$f t s Z$ & TACCATACTCAGCGGCTTTC & GCGCCTGTAGTTGCTGAAGT & $112 \mathrm{bp}$ & 1.986 & 1.997 & 12952792 & $\begin{array}{l}136099- \\
136210\end{array}$ \\
\hline ribc & ATCTCAACTAGCCACGCTCC & CGGTGGACACATGGTACAAG & $87 \mathrm{bp}$ & 1.946 & 1.950 & 12952738 & $\begin{array}{l}84136- \\
84222\end{array}$ \\
\hline $\begin{array}{l}\text { 16S } \\
\text { rRNA }\end{array}$ & $\begin{array}{l}\text { AACGACTGTTAATACCGCATAATATCTG } \\
{[17]}\end{array}$ & $\begin{array}{l}\text { CCTTACCCTACCAACTAGCTAATCCA } \\
{[17]}\end{array}$ & $101 \mathrm{bp}$ & 1.954 & 1.954 & 12951375 & $\begin{array}{l}463870- \\
463970\end{array}$ \\
\hline$i g / C$ & TAGGCGTATAACACTGGCTGC & TGCTATAGAAGGCGGAGAGG & $70 \mathrm{bp}$ & 2.006 & 1.905 & 12951826 & $\begin{array}{l}930145- \\
930214\end{array}$ \\
\hline
\end{tabular}

The complete genome of F. noatunensis ssp. orientalis strain Toba 04 (Accession number NC_017909), was used as a reference to assign the Gene ID.

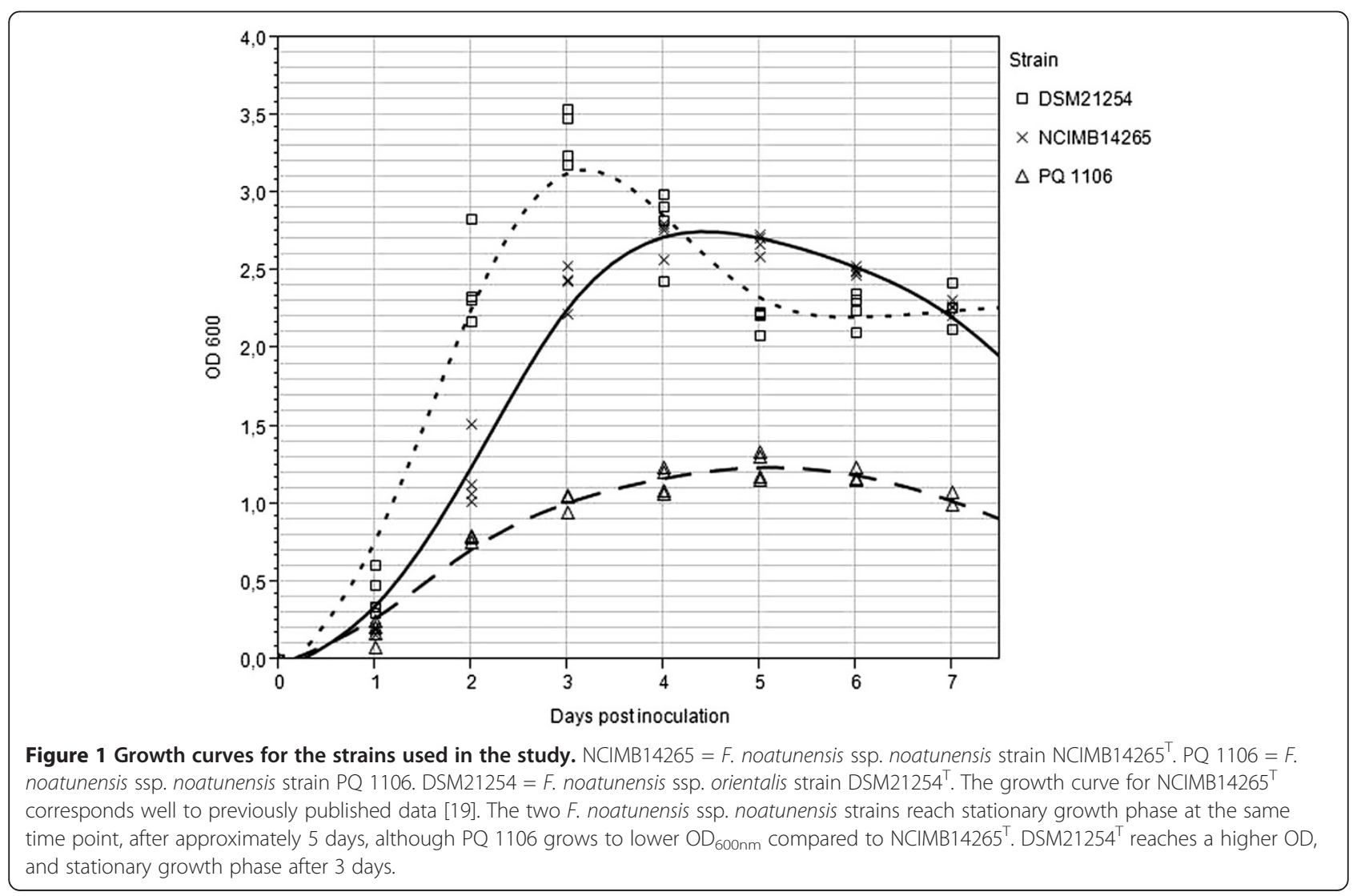


Table 2 Expression stability index (M-value) and ranking of the candidate reference genes

\begin{tabular}{|c|c|c|c|c|c|c|c|c|}
\hline & & & & M-value & & & & \\
\hline Strain & $f t s z$ & polA & fopA & ribC & gyrA & uvrD & $16 S$ rRNA & $r p o B$ \\
\hline $\mathrm{NCIMB} 14265^{\top}$ & 0.531 & 0.818 & 0.531 & 0.751 & 0.949 & 1.050 & 2.004 & 2.563 \\
\hline DSM21254 ${ }^{\top}$ & 0.555 & 0.692 & 0.716 & 1.009 & 0.555 & 0.892 & 1.496 & 2.343 \\
\hline PQ 1106 & 0.603 & 0.603 & 0.653 & 0.842 & 0.880 & 1.241 & 2.570 & 1.781 \\
\hline All strains combined & 0.979 & 0.790 & 1.535 & 0.790 & 1.498 & 1.675 & 2.411 & 2.126 \\
\hline Ranking order & 1 & 2 & 3 & 4 & 5 & 6 & 7 & 8 \\
\hline
\end{tabular}

The lowest M-value corresponds to the most stable gene.

\section{Reference gene validation}

Quantitative PCR carried out with the Stratagene Mx3005 thermal cycler (Stratagene, La Jolla, San Diego, CA) was performed in a $25 \mu \mathrm{l}$ reaction volume containing $2 \mu \mathrm{l}$ of the appropriate cDNA or genomic DNA, $12.5 \mu \mathrm{l} 2 \times$ High power SYBR green PCR Master Mix (Applied Biosystems) and $300 \mathrm{nM}$ concentration of the appropriate forward and reverse primers (Invitrogen). The thermal cycling conditions for the PCR were as follows: 1 cycle at $95^{\circ} \mathrm{C}$ for $10 \mathrm{~min}, 45$ cycles of amplification at $95^{\circ} \mathrm{C}$ for $15 \mathrm{~s}$ and annealing at $60^{\circ} \mathrm{C}$ for $1 \mathrm{~min}$. The data were collected during each elongation step. Melting-curve analysis consisting of 1 cycle at $95^{\circ} \mathrm{C}$ for $30 \mathrm{~s}, 55^{\circ} \mathrm{C}$ for $30 \mathrm{~s}$ and $95^{\circ} \mathrm{C}$ for $30 \mathrm{~s}$ was also performed after SYBR green I PCR to check the specificity of the amplification products. Negative (DEPC treated $\mathrm{H}_{2} \mathrm{O}$ ) and no-reverse transcriptase controls were included in each run. All samples and controls were analyzed in triplicate.

The data was analyzed using the excel-based software geNorm [12], which compares the relative expression of reference genes in a pair-wise manner, and awards an
M-value (expression stability) to each gene. The lowest $\mathrm{M}$-value corresponds to the most stable reference gene. The worst scoring reference gene was then excluded from the analysis, and the process repeated in a step-wise manner until only the two best reference genes remained. The reference genes were ranked 1-8, with the most stable reference gene given the lowest value. The overall stability of each reference gene was determined by the sum of the ranking values from all four datasets combined. For calculation of the number of reference genes needed for reliable quantification of a target gene, the recommended cut-off for the pair-wise variation value $\mathrm{V}$ of 0.15 was used.

\section{Normalization of iglC transcription}

The relative transcription of the potential virulence gene $i g l C$ was investigated using the reference genes recommended by geNorm. For NCIMB $14265^{\mathrm{T}}$ and DSM $21254^{\mathrm{T}}$, the five most stably transcribed reference genes were used, while for PQ 1106, the four most stably expressed reference genes were used. The relative transcription of iglC was determined in all samples by normalization

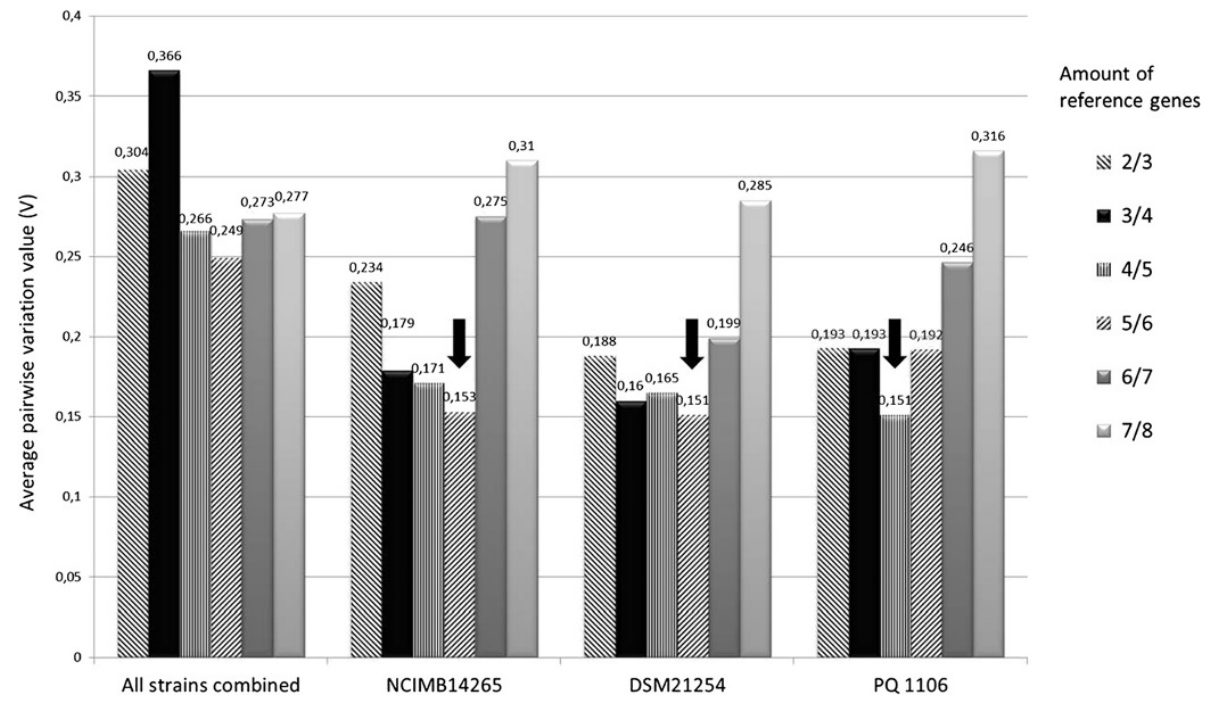

Figure 2 Average pairwise variation value V. $\mathrm{NCIMB} 14265=F$. noatunensis ssp. noatunensis strain $\mathrm{NCIMB} 14265^{\top}$. $\mathrm{PQ} 1106=F$. noatunensis ssp. noatunensis strain PQ 1106. DSM21254 = F. noatunensis ssp. orientalis strain DSM21254 ${ }^{\top}$. Arrows indicate the number of reference genes needed for accurate normalization of a target gene for each strain. 


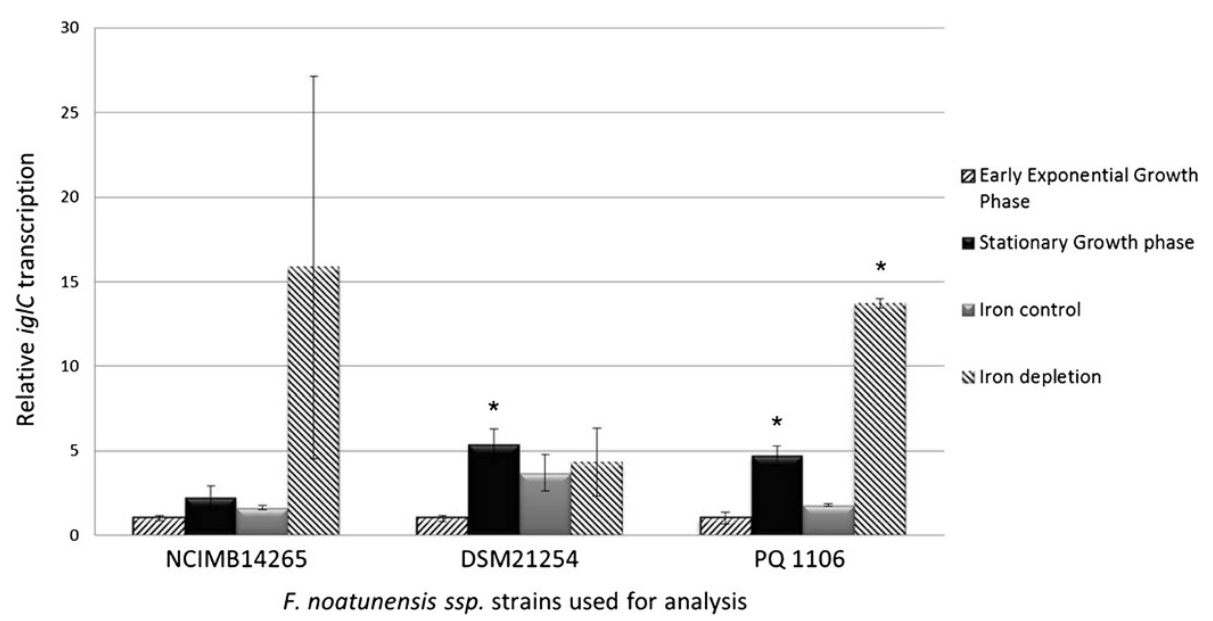

Figure 3 Statistical analysis of differential transcription of ig/C under different growth conditions. Stars denote statistically significant differences with $p$-value $<0.05$. Bars indicate standard error of the mean. NCIMB14265 $=F$. noatunensis ssp. noatunensis strain NCIMB14265 ${ }^{\top}$. PQ $1106=$ F. noatunensis ssp. noatunensis strain PQ 1106. DSM21254 = F. noatunensis ssp. orientalis strain DSM21254 .

against a normalization factor calculated by geNorm (based upon the geometric mean of the selected reference genes). The normalized values were divided by the arithmetic mean of the normalized log-phase expression values of $\mathrm{iglC}$ of each strain for presentation purposes. The statistical analysis of the normalized iglC transcription data was performed using JMP 8.0.2. (SAS Institute Inc.). The difference in iglC transcription levels between different growth phases, and the effect of an iron-depleted medium, were compared and determined as statistically significant if $p$-value $<0.05$ by Student's t-test assuming unequal variance.

\section{Results}

\section{Primer specificity and efficiency}

Melting curve analysis revealed good specificity for the target genes with single peaks obtained for all primer sets. The primer efficiencies and amplicon size are shown in Table 1.

\section{Transcription and stability of reference genes}

To identify stably expressed reference genes in F. noatunensis ssp., eight candidate reference genes were initially analyzed. The bacterial cells were harvested in early exponential $\left(\mathrm{OD}_{600 \mathrm{~nm}}\right.$ 0.3-0.5) growth phase and upon entry into stationary phase at 3 and 5 days post-inoculation for ssp. orientalis and ssp. noatunensis strains, respectively (see Figure 1). The purity of extracted total RNA used for reverse transcription was good, with 260/280 ratios above 2.1 , and 260/230 ratios above 2.2 in all samples. No RNA degradation was observed as evaluated by gel electrophoresis. The data from the three strains combined suggested polA, ribC and fts $Z$ as the most stably transcribed reference genes across all strains, as indicated by the lowest M-values (Table 2). The pooled data, however, could not be used for analysis due to substantial pairwise variation (Figure 2). On individual analysis, we identified stably expressed reference genes for each strain. For $F$. noatunensis ssp. noatunensis NCIMB $14265^{\mathrm{T}}$, fop $A, f t s Z$ and $r i b C$ were the three most stably transcribed genes, while fts $Z$, pol $A$ and $f o p A$; and $f t s Z$, gyrA and polA were the three most stably transcribed genes in F. noatunensis ssp. noatunensis PQ 1106 and F. noatunensis ssp. orientalis DSM21254 ${ }^{\mathrm{T}}$, respectively. Regardless of strain studied, $16 S \mathrm{rRNA}$ and $r p o B$ consistently scored worst, and therefore constitute poor reference genes for gene transcription studies in Francisella noatunensis ssp. The optimal number of reference genes for each strain was determined based upon the average pairwise variation value $\mathrm{V}$ calculated by geNorm (Figure 2). For NCIMB14265 ${ }^{\mathrm{T}}$ and DSM21254 ${ }^{\mathrm{T}}$, the optimal number of reference genes is five, while for PQ 1106 the optimal number is four.

\section{Effect of growth phase and culture conditions on ig/C transcription}

The selected reference genes were used to assess the possible differential expression of $i g l C$, which is known to be regulated by environmental cues [20,21]. All three strains displayed increased transcription of $i g l C$ in stationary compared to exponential growth phase, although for strain NCIMB $14265^{\mathrm{T}}$ the increase was not statistically significant (see Figure 3). Transcription increases of 3.69 fold and 4.32 fold were recorded for $i g l C_{\mathrm{PQ}} 1106$ and ${ }_{i g l} C_{\mathrm{DSM} 21254}{ }^{T}$, respectively. In an iron-depleted medium, PQ 1106 displayed a significant 6.72 fold increase in $\mathrm{iglC}$ transcription and a trend towards increased transcription 
was identified in NCIMB14265 ${ }^{\mathrm{T}}$ (8.79 fold). No such increase was observed in DSM21254 ${ }^{\mathrm{T}}$.

\section{Discussion}

Identification of bacterial reference genes stably transcribed in the stationary growth phase can be challenging [22]. This is probably due to the physiological changes occurring in a bacterial culture on adaption to a nutrientdepleted environment, as reviewed by Navarro Llorens et al. [23]. We did, however, identify several reference genes which are stably transcribed during exponential growth, stationary growth and in an iron-depleted environment. While transcription stability of the various reference genes varied slightly in the three strains, fts $Z$, polA and fopA provided relatively good scores for individual strains with geNorm expression stability measures below 1.0, which has been regarded as suitable for normalization in several studies [24-26]. Subspecies differences were apparent in our dataset. The four top scoring reference genes were identical in both strains of $F$. noatunensis ssp. noatunensis, although they ranked differently. The observed differences between ssp. noatunensis and orientalis may be explained by inter-strain evolutionary distances. Although several genes may appear useful for evaluation of gene transcription in the tested $F$. noatunensis strains, $16 S$ rRNA and rpoB should be discouraged unless these genes are properly validated for each experimental condition.

On examination of $i g l C$ transcription in relation to bacterial growth phase, all strains show a trend toward higher iglC transcription in stationary compared to early exponential growth phase. The increase was, however, only statistically significant in two of the three studied strains (PQ 1106 and DSM21254 $4^{\mathrm{T}}$ ). The iglC gene has been shown to be important for intracellular growth in F. noatunensis ssp. orientalis [27]. The nutrient-depleted environment encountered in the stationary growth phase may mimic some aspects of the intra macrophage environment. Virulence associated factors, up-regulated in the stationary growth phase have also been shown in other intracellular pathogenic bacteria $[28,29]$ to be upregulated in infected macrophages. Our results indicate that transcription of $i g l C$ is increased in an environment mimicking intracellular conditions, thus suggesting a virulence-related intracellular survival role for this gene in $F$. noatunensis ssp.

The overall increase in $i g l C$ transcription in $F$. noatunensis ssp. noatunensis strains in an iron-depleted environment is consistent with the situation in F. tularensis ssp. holarctica Live Vaccine Strain [20]. Exposure to ironlimitation after reaching stationary growth phase might have prevented further induction of $\mathrm{iglC}$ transcription in DSM21254 $4^{\mathrm{T}}$. This is partially supported by data from the early logarithmic growth, where a 3.31 fold increase in $i g l C$ transcription was observed.

Generally, analysis of RT-qPCR gene expression data using a single reference gene is not acceptable, as inclusion of multiple reference genes results in much more accurate and reliable normalization. The geNorm calculated $\mathrm{V}$ values give the optimal number of reference genes to be used in an expression study [12]. Although the use of three reference genes is a valid normalization strategy in most cases, our results showed that four to five reference genes are required to achieve accurate normalization of gene transcription in all $F$. noatunensis ssp. Besides increasing the workload and cost, applying a large reference gene set could also pose constraints on limited sample availability. On normalization of $i g l C$ transcription with the three most stable genes across all three strains, we achieved basically the same results as normalizing with the optimal number of four or five reference genes, but with a slightly higher degree of variation (data not shown). Thus, it is always a trade-off between accuracy and practical considerations when it comes to the optimal number of reference genes to include in the analysis. For accurate quantification of small changes in gene transcription, it might be desirable to use the specified optimal number of reference genes. However, if only large differences in gene transcription are of interest, use of a smaller number of stably expressed reference genes might be justifiable.

In conclusion, the present study investigated the most reliable reference genes for normalization of gene expression data in $F$. noatunensis under different in vitro growth conditions. Although there were many potential suitable references genes, fts $Z$, polA and fop $A$ were the best, while $16 S$ rRNA and rpoB proved to be the least stable under all tested conditions. These data emphasize the need for proper validation of candidate reference genes in any experimental expression study. Extrapolation of results from one strain to another must therefore be done with extreme caution. It also provides baseline data on selection of reference genes for many future studies investigating expression of virulence in pathogenic Francisella strains.

\section{Availability of supporting data}

The dataset supporting the results of this article is included within the article (and its additional file).

\section{Additional file}

Additional file 1: List of reference genes used in publications for RT-qPCR gene expression analyses in Francisella spp. [30-43].

Competing interests

We declare no competing interests. 


\section{Authors' contributions}

BE performed the experiments, analyzed and interpreted the data and wrote the manuscript. WLHC and CDJ were involved in the design, interpretation of the data and writing of the manuscript. DS designed and performed some of the experiments, was involved in the interpretation of the data and writing of the manuscript. All authors read and approved the final manuscript.

\section{Acknowledgements}

This work was supported financially by the Norwegian Research Council (Grant no. 185362) and the Norwegian School of Veterinary Science (NSVS), to whom we express our gratitude.

\section{Author details}

'Section for Microbiology, Immunology and Parasitology, Department of Food Safety and Infection Biology, Norwegian School of Veterinary Science, PO Box 8146 Dep, Oslo 0033, Norway. ' Laboratory for Microbial Dynamics (LaMDa), University of Oslo, PO Box 1068, Blindern, Oslo 0316, Norway. ${ }^{3}$ School of Pharmacy, University of Oslo, PO Box 1068, Blindern, Oslo 0316, Norway. ${ }^{4}$ Section for Bacteriology, Norwegian Veterinary Institute, PO Box 750, Sentrum 0106, Oslo, Norway.

Received: 21 December 2012 Accepted: 27 February 2013

Published: 2 March 2013

\section{References}

1. Kamaishi T, Fukuda Y, Nishiyama M, Kawakami M, Matsuyama T, Yoshinaga T, Oseko N: Identification and pathogenicity of intracellular Francisella bacterium in three-line grunt Parapristipoma trilineatum. Fish Pathology 2005, 40:67-71.

2. Birkbeck TH, Bordevik M, Frøystad MK, Baklien A: Identification of Francisella sp. from Atlantic salmon, Salmo salar L., in Chile. J Fish Dis 2007, 30:505-507.

3. Mauel MJ, Soto E, Moralis JA, Hawke J: A piscirickettsiosis-like syndrome in cultured Nile tilapia in Latin America with Francisella spp. as the pathogenic agent. J Aquat Anim Health 2007, 19:27-34.

4. Jeffery KR, Stone D, Feist SW, Verner-Jeffreys DW: An outbreak of disease caused by Francisella sp. in Nile tilapia Oreochromis niloticus at a recirculation fish farm in the UK. Dis Aquat Organ 2010, 91:161-165.

5. Sjödin A, Svensson K, Öhrman C, Ahlinder J, Lindgren P, Duodu S, Hnath J, Burans JP, Johansson A, Colquhoun DJ: Genome characterisation of the genus Francisella reveals insight into similar evolutionary paths in pathogens of mammals and fish. BMC Genomics 2012, 13:268.

6. Nano FE, Zhang N, Cowley SC, Klose KE, Cheung KK, Roberts MJ, Ludu JS, Letendre GW, Meierovics Al, Stephens G: A Francisella tularensis pathogenicity island required for intramacrophage growth. J Bacteriol 2004, 186:6430-6436.

7. Larsson P, Oyston PC, Chain P, Chu MC, Duffield M, Fuxelius HH, Garcia E, Hälltorp G, Johansson D, Isherwood KE, Karp PD, Larsson E, Liu Y, Michell E, Prior J, Prior R, Malfatti S, Sjöstedt A, Svensson K, Thompson N, Vergez L, Wagg JK, Wren BW, Lindler LE, Andersson SG, Forsman M, Titball RW: The complete genome sequence of Francisella tularensis, the causative agent of tularemia. Nat Genet 2005, 37:153-159.

8. Soto E, Fernandez D, Hawke JP: Attenuation of the fish pathogen Francisella sp. by mutation of the iglC* gene. J Aquat Anim Health 2009, 21:140-149.

9. Soto E, Wiles J, Elzer P, Macaluso K, Hawke JP: Attenuated Francisella asiatica ig/C mutant induces protective immunity to francisellosis in tilapia. Vaccine 2010, 29(3):593-598.

10. Dheda K, Huggett JF, Chang JS, Kim LU, Bustin SA, Johnson MA, Rook GA, Zumla A: The implications of using an inappropriate reference gene for real-time reverse transcription PCR data normalization. Anal Biochem 2005, 344:141-143.

11. Gutierrez L, Mauriat M, Guenin S, Pelloux J, Lefebvre JF, Louvet R, Rusterucci C, Moritz T, Guerineau F, Bellini C: The lack of a systematic validation of reference genes: a serious pitfall undervalued in reverse transcriptionpolymerase chain reaction (RT-PCR) analysis in plants. Plant Biotechnol J 2008, 6:609-618.

12. Vandesompele J, De PK, Pattyn F, Poppe B, Van RN, De PA, Speleman F: Accurate normalization of real-time quantitative RT-PCR data by geometric averaging of multiple internal control genes. Genome Biol 2002, 3:RESEARCH0034.1-RESEARCH0034.11.

13. Huggett J, Dheda K, Bustin S, Zumla A: Real-time RT-PCR normalisation; strategies and considerations. Genes Immun 2005, 6:279-284.

14. Bustin SA, Benes V, Garson JA, Hellemans J, Huggett J, Kubista M, Mueller R, Nolan T, Pfaffl MW, Shipley GL: The MIQE guidelines: minimum information for publication of quantitative real-time PCR experiments. Clin Chem 2009, 55:611-622.

15. Bustin SA: Why the need for qPCR publication guidelines?-The case for MIQE. Methods 2010, 50:217-226.

16. Olsen AB, Mikalsen J, Rode M, Alfjorden A, Hoel E, Straum-Lie K, Haldorsen $\mathrm{R}$, Colquhoun DJ: A novel systemic granulomatous inflammatory disease in farmed Atlantic cod, Gadus morhua L., associated with a bacterium belonging to the genus Francisella. J Fish Dis 2006, 29:307-311.

17. Ottem KF, Nylund A, Isaksen TE, Karlsbakk E, Bergh Ø: Occurrence of Francisella piscicida in farmed and wild Atlantic cod, Gadus morhua L., in Norway. J Fish Dis 2008, 31:525-534.

18. BioRad technical note 5396. http://www3.biorad.com/cmc_upload/Literature/ 195246/Bulletin 5396.pdf

19. Furevik A, Pettersen EF, Colquhoun D, Wergeland HI: The intracellular lifestyle of Francisella noatunensis in Atlantic cod (Gadus morhua L.) leucocytes. Fish Shellfish Immunol 2011, 30:488-494.

20. Deng K, Blick RJ, Liu W, Hansen EJ: Identification of Francisella tularensis genes affected by iron limitation. Infect Immun 2006, 74:4224-4236.

21. Hazlett KRO, Cirillo KA: Environmental Adaptation of Francisella tularensis. Microbes Infect 2009, 11:828-834.

22. Derzelle S, Dilasser F, Duquenne M, Deperrois V: Differential temporal expression of the staphylococcal enterotoxins genes during cell growth. Food Microbiol 2009, 26:896-904.

23. Navarro Llorens JM, Tormo A, Martinez-Garcia E: Stationary phase in gram-negative bacteria. FEMS Microbiol Rev 2010, 34:476-495.

24. Nielsen KK, Boye M: Real-time quantitative reverse transcription-PCR analysis of expression stability of Actinobacillus pleuropneumoniae housekeeping genes during in vitro growth under iron-depleted conditions. Appl Environ Microbiol 2005, 71(6):2949-2954.

25. Botteldoorn N, Van Coillie E, Grijspeerdt K, Werbrouck H, Haesebrouck F, Donné E, D'Haese E, Heyndrickx M, Pasmans F, Herman L: Real-time reverse transcription PCR for the quantification of the $\mathrm{mntH}$ expression of Salmonella enterica as a function of growth phase and phagosome-like conditions. J Microbiol Methods 2006, 66:125-135.

26. Tasara T, Stephan R: Evaluation of housekeeping genes in Listeria monocytogenes as potential internal control references for normalizing mRNA expression levels in stress adaptation models using real-time PCR. FEMS Microbiol Lett 2007, 269:265-272.

27. Soto E, Fernandez D, Thune R, Hawke JP: Interaction of Francisella asiatica with tilapia (Oreochromis niloticus) innate immunity. Infect Immun 2010, 78:2070-2078

28. Byrne B, Swanson MS: Expression of Legionella pneumophila virulence traits in response to growth conditions. Infect Immun 1998, 66:3029-3034.

29. Kumar A, Bose M, Brahmachari V: Analysis of expression profile of mammalian cell entry (mce) operons of Mycobacterium tuberculosis. Infect Immun 2003, 71:6083-6087.

30. Wehrly TD, Chong A, Virtaneva K, Sturdevant DE, Child R, Edwards JA, Brouwer D, Nair V, Fischer ER, Wicke L, et al: Intracellular biology and virulence determinants of Francisella tularensis revealed by transcriptional profiling inside macrophages. Cell Microbio/ 2009, 11:1128-1150.

31. Ramakrishnan G, Meeker A, Dragulev B: $f \mathbf{S I E}$ is necessary for siderophoremediated iron acquisition in Francisella tularensis Schu S4. J Bacteriol 2008, 190:5353-5361

32. Carlson PE Jr, Carroll JA, O'Dee DM, Nau GJ: Modulation of virulence factors in Francisella tularensis determines human macrophage responses. Microb Pathog 2007, 42:204-214.

33. Horzempa J, Carlson PE Jr, O'Dee DM, Shanks RM, Nau GJ: Global transcriptional response to mammalian temperature provides new insight into Francisella tularensis pathogenesis. BMC Microbiol 2008, 8:172.

34. Postic G, Frapy E, Dupuis M, Dubail I, Livny J, Charbit A, Meibom KL: Identification of small RNAs in Francisella tularensis. BMC Genomics 2010, 11:625.

35. Grall N, Livny J, Waldor M, Barel M, Charbit A, Meibom KL: Pivotal role of the Francisella tularensis heat-shock sigma factor RpoH. Microbiology 2009, 155:2560-2572. 
36. Soni S, Ernst RK, Muszynski A, Mohapatra NP, Berry MP, Vinogradov E, Carlson RW, Gunn JS: Francisella tularensis blue-gray phase variation involves structural modifications of lipopolysaccharide O-antigen, core and lipid $A$ and affects intramacrophage survival and vaccine efficacy. Front Microbiol 2011, 1:129.

37. Sullivan JT, Jeffery EF, Shannon JD, Ramakrishnan G: Characterization of the siderophore of Francisella tularensis and role of $f s / A$ in siderophore production. J Bacteriol 2006, 188:3785-3795.

38. Charity JC, Costante-Hamm MM, Balon EL, Boyd DH, Rubin EJ, Dove SL: Twin RNA polymerase-associated proteins control virulence gene expression in Francisella tularensis. PLoS Pathog 2007, 3(6):e84.

39. Buchan BW, McCaffrey RL, Lindemann SR, Allen LA, Jones BD: Identification of $m i g R$, a regulatory element of the Francisella tularensis live vaccine strain igI $A B C D$ virulence operon required for normal replication and trafficking in macrophages. Infect Immun 2009, 77:2517-2529.

40. Bell BL, Mohapatra NP, Gunn JS: Regulation of virulence gene transcripts by the Francisella novicida orphan response regulator PmrA: role of phosphorylation and evidence of MgIA/SspA interaction. Infect Immun 2010, 78:2189-2198.

41. Mohapatra NP, Soni S, Bell BL, Warren R, Ernst RK, Muszynski A, Carlson RW Gunn JS: Identification of an orphan response regulator required for the virulence of Francisella spp. and transcription of pathogenicity island genes. Infect Immun 2007, 75:3305-3314.

42. Brotcke A, Weiss DS, Kim CC, Chain P, Malfatti S, Garcia E, Monack DM: Identification of MglA-regulated genes reveals novel virulence factors in Francisella tularensis. Infect Immun 2006, 74:6642-6655.

43. Brotcke A, Monack DM: Identification of fevR, a novel regulator of virulence gene expression in Francisella novicida. Infect Immun 2008, 76:3473-3480.

doi:10.1186/1756-0500-6-76

Cite this article as: Brudal et al.: Evaluation of reference genes for reverse transcription quantitative PCR analyses of

fish-pathogenic Francisella strains exposed

to different growth conditions. BMC Research Notes 2013 6:76.

\section{Submit your next manuscript to BioMed Central and take full advantage of:}

- Convenient online submission

- Thorough peer review

- No space constraints or color figure charges

- Immediate publication on acceptance

- Inclusion in PubMed, CAS, Scopus and Google Scholar

- Research which is freely available for redistribution 